DRAFT $9 / 22 / 11 \quad$ Comments invited

\title{
Looking Behind Community College Budgets for Future Policy Considerations
}

By: Richard M. Romano

Director, Institute for Community College Research, Broome Community College/State University of New York, Binghamton, N.Y. and Research Fellow, Cornell Higher Education Research Institute, Cornell University, Ithaca, N.Y.

\section{ABSTRACT}

This study reviews the historical trend of college revenues and expenditures from a national perspective. The years 1999-2009 are examined with the most detail using primarily Delta Project/IPEDS data. Looking at trends related to state and local appropriations, college costs and prices, output, and productivity, it argues that various policy issues flow from these trends. The recommendations that follow are not precise prescriptions for legislative action, but rather suggestions for the direction of public and institutional policy that invite further reflection and research.

Corresponding author:

\author{
Richard M. Romano \\ Broome Community College \\ PO Box 1017
}

Binghamton, NY 13902

Cell phone: 607-759-0488; fax: 607-778-5173

Email: rmr46@cornell.edu 
DRAFT 9/22/11 Comments invited: $\underline{\text { rmr46@cornell.edu }}$ Looking Behind Community College Budgets for Future Policy Considerations

By Richard M. Romano

It's pretty much a given that community college administrators will complain about their budgets no matter what the circumstances. There never seems to be enough money to support the multiple missions pursued by these colleges. During the great recession, which emerged in 2008 , and the sluggish recovery that followed, however, their cries seem more urgent.

Although exact current numbers are not so easy to obtain, given the lag in data collection, most states had very difficult budget years in 2009, 2010 and 2011. This impacted their appropriations to community colleges at the same time enrollments were increasing. When looking at national data on community colleges, we see enrollments in credit-bearing courses surging $11.4 \%$ from fall 2008 to fall 2009 and $16.9 \%$ from fall 2007 to fall 2009 (Mullin \& Phillippe, 2009). At the same time, state and local appropriations for higher education, (per FTE in constant dollars), declined by 5.1 percent in 2009 and 7.1 percent in 2010 (SHEEO, 2010). The outlook for 2011-12 remains gloomy with slow economic growth expected to continue, economic stimulus funds running out, the global debt crisis destabilizing markets, a huge unfunded state and local government pension crisis looming and a more conservative political environment anxious to reduce public spending (Boyd, 2009). Further research into the rollercoaster ride of higher education enrollments and appropriations, particularly for community colleges, can help us better anticipate the future. 


\section{A little history}

It is well documented that enrollments in the community college have increased at an uneven but steady pace for the past 40 years. Growing from 1.2 million students in 1966 to 6.2 million in 2006, they have added more students and grown at a faster rate than public four-year colleges (NCES, 2008, Table SA-4). Over this same 40 year period, state and local appropriations had grown, in current dollars, to over \$25 billion by 2006 (NCES, 2010, Table 352). Yet both enrollments and public appropriations have varied with the business cycle.

In one of the best studies of its kind, Betts and McFarland (1996) plot the enrollments and state and local appropriations at individual community colleges in all areas of the country, between the late 1960's and mid-1980's. They find that enrollments, even after controlling for other factors that affect demand, are very sensitive to the unemployment rate. That is, as the economy contracts and unemployment rises, so does enrollment. Nationally, they find that a one percent increase in the unemployment of recent high school graduates is associated with a 0.5 percent increase in full-time attendance. For older workers, a one percent rise in unemployment increases community college enrollments by four percent as these workers seek retraining opportunities. Part-time enrollments show similar countercyclical patterns.

In contrast, Betts and McFarland (1996) find that state and local appropriations are procyclical. That is, during periods of rising unemployment, appropriations fall as state and local government budgets are strained. But some recovery in appropriations occurs during more prosperous times. The authors argue that, ideally, funding should be more closely linked to labor market conditions, which suggests that public funding should also be countercyclical: 
rising more during periods of unemployment than during periods of more rapid economic growth. This would give community colleges money to serve students at times when they need it the most.

Another detailed study of public funding of higher education over the business cycle was done by Rizzo $(2004,2006)$. He constructs an extensive state-level dataset covering the period 1976 to 2001 and finds that, looking at budget shares, public funding of higher education has not always moved in tandem with the business cycle. This has resulted in a steady decline in support for public higher education over three decades. After an increase in the early 1970s, the share of states' general fund expenditures for all levels of education fell from $39.9 \%$ in 1972 to $36.1 \%$ in 2001 . This relative decline in funding was found in all but 11 states. In turn, within the state budget for education, the proportion going to higher education fell from $22.6 \%$ to $16.4 \%$ in the same period, as states traded off spending on colleges for K-12 education. Even the good state budget years of the 1990s were not generous enough to restore the importance of higher education to previous levels. Rizzo's econometric analysis leads him to argue that the relative decline in state funding for education did not result only from a crowding out by spending on other programs, such as health care and corrections, but also from a general decline in political preference for education. Rizzo concludes "that public higher education has steadily fallen out of favor as a budgetary priority - even during robust economic times" (Rizzo, 2004, p.14).

In the most recent examination of the cyclical swing in state funding for higher education, Delaney and Doyle (2011) look at data for 49 states from 1985-2004. They find good evidence 
to support the idea that higher education appropriations serve as a balance wheel for state budgets, rising in good years but falling disproportionately in bad ones.

This decline in relative preference for higher education has not bypassed the community college. In a detailed study of state and local funding for community colleges, Roessler (2006) found that the percentage of operating budget revenues coming from state appropriations declined from $47.1 \%$ in 1981 to $34 \%$ in 2001 , in constant dollars. Just three states saw increases during this 20-year period. At the same time, the local funding share of the budget fell from $17.4 \%$ to $14.7 \%$. In response, revenue from tuition and fees as a share of community college budgets increased from $15.6 \%$ in 1981 to $19.2 \%$ in 2001 . Of course differences existed between the states, with the largest decline in state appropriations coming from Vermont which contributed $44.6 \%$ of the budget in 1981 but only $10.9 \%$ in 2001.

Katsinas and Friedel (2010) have stated the secular decline in preference for funding community colleges in another way: "In 1980-81, 16 states contributed $60 \%$ or more of total revenues for their community colleges; in 2000-01, none did" (p. 3).

Before we look at more recent data, let's be reminded that our discussion thus far is all about the revenue side of college budgets. Theoretically, colleges would need more revenue each year for two principle reasons. First, increases in enrollment require additional expenditures. Second, the cost per student continues to rise. This last point leads us to consider the cost side of the college budget which is equally important but much less discussed than the need for additional revenue. 


\section{A little theory}

The chief reason for the rise in tuition and fees in public sector colleges in recent years has been the steady decline in state and local appropriations as a share of operating budgets. Irrespective of this, the rising cost of producing this education is generally acknowledged to be a basic force which is pushing up the price of attending college. It is this rising cost that must ultimately be controlled if tuition is to be stabilized or even reduced. Looking at the cost side of the budget forces us to examine the relationship between costs, productivity and prices.

In traditional economic theory producers in private enterprise markets are faced with decisions about what to charge for their goods or services in light of market conditions. These conditions include what they must pay for the inputs of producing that service. If costs, including wages, go up faster than productivity then prices will rise and/or profit margins will fall. In very competitive markets, if buyers do not accept these higher prices the producers must find lower cost alternatives or go out of business. In the long run, wages can rise, other things being equal, without an increase in price, only if productivity rises. Productivity is measured by increasing output, of a given quality, with the same or fewer resources. Technological change and the substitution of capital for labor are key ingredients in rising productivity. In some industries, such as electronics, rapidly rising productivity spurred by technological change allows for not only rising wages in that industry but also falling prices. What about higher education?

In higher education, costs have been rising faster than the general rate of inflation. In searching for an explanation of this, economists have postulated two distinct theories of college cost. The first was suggested by William Baumol and William Bowen (Baumol, 1967; Baumol \& 
Bowen, 1966; Baumol \& Blackman, 1995) and might be labeled the low productivity theory of cost or the "cost disease" explanation. This theory suggests that education belongs to a class of industries where productivity is difficult to increase (without reducing quality) but where producers are forced to pay competitive wages and prices to attract the inputs needed for production. Medicine, good restaurants and symphony orchestras also fit this category. In industries where productivity growth is slower than that in the overall economy, costs will always rise faster than the general rate of inflation. Thus, more revenue is needed "to help offset rising costs associated with slow productivity growth in the very labor intensive higher education industry" (Weisbrod, Ballou \& Asch, 2008, p.131).

The second theory of costs is the revenue theory. According to this theory, put forth by Howard Bowen (1980), colleges spend all of the revenue you give them. So, holding down costs means holding down revenue. This theory has political appeal in certain quarters. Breneman (2000), provides a simple statement of these two theories and Archibald and Feldman (2008) tested the two theories. They concluded that the cost disease is the "dominant reason that higher education costs have risen... over the past 80 years" (p.289). Neither of these theories has been tested on the community college, but it is assumed that the dominant "cost disease" theory holds for them as well.

Of course, it is possible that the increasing cost of higher education is paying for a higher quality output, be it student learning, the number of degrees or some other measure of output. Quality is an unknown factor at this time because we have no standard measure of it. It is possible that quality is going down and that rising costs and lower appropriations are still 
pushing prices up. Even if we could show that instructional costs, for instance, were falling and productivity was rising, it may not be reflected in lower tuition and public subsidies as colleges might use whatever surplus revenue they generate to meet other needs.

\section{More recent data (1999-2009)}

\section{Data sources}

Looking at the aggregate revenue and expenditures of colleges can give us a national perspective on what's happening to college budgets. However, data collection lags mean that expenditures and revenues for the years starting in 2010 are incomplete. In addition, data for community colleges is less accessible than the same figures for all of public higher education because state budgets sometimes do not separate the two. National data for community colleges are available from two principle sources, the Grapevine survey and the U.S. Department of Education IPEDS database.

The Grapevine-The results of this survey have been published annually, separating state and local appropriations into two categories; "state- aided community colleges" where local tax appropriations make up a significant proportion of institutional revenue (at least 10\%) and "state community colleges" where colleges receive little or no local appropriations (www.grapevine.ilstu.edu). The Grapevine does not publish data on expenditures. The last set of data reported for community colleges by the Grapevine was for the fiscal year 2009. For that year appropriations declined by $0.3 \%$ for the "state community colleges" and rose by $2.0 \%$ for the "state-aided community colleges," but these figures are not adjusted for inflation or enrollments.1 
Starting in 2010, the Grapevine survey of state offices was combined with a similar effort by SHEEO for its SHEF project. Now only state appropriations for all of higher education are reported. The Grapevine/SHEEO survey asks the states for community college appropriations but not all are reporting it. If this does not change we will have lost a valuable source of data on community college finance. 2

It is worth mentioning a related source of timely information, but not actual data, about community college appropriations that is available from the Education Policy Center at the University of Alabama. They survey the State Directors of community colleges about the status of community college funding in their state. "Most of the results presented are the respondents' perceptions, not actual measures," but they do give us reasonable estimates of what the states are thinking (Katsinas \& Friedel, 2010, p.10). The most recent survey of State Directors found that 34 out of 50 states reported mid-year budget cuts for community colleges in 2009 and 28 expected such cuts in 2010 (Katsinas \& Friedel,2010). This was a large increase over 2007 and 2008 where only two and nine states, respectively, reported such cuts.

IPEDS/Delta---The second source of available data on community colleges is from IPEDS. This institutional level data is available in an improved and user friendly form through the Delta Project (its full name is the Delta Project on Postsecondary Education Costs, Productivity and Accountability). The Delta Project dataset is an improvement over IPEDS because it imputes small amounts of missing data and supplements IPEDS with other national data where necessary. It also adjusts the IPEDS data for changes in accounting procedures which make multiyear comparisons of expenditures and revenues more accurate. 
The latest data from the Delta Project is for 2009 but it was not published until the summer of 2011. I have used an advanced early copy of this data as the primary source of information for Tables 1-3 below.

Appropriations/Revenue

Looking at past research, I have argued that the relative decline in state and local appropriations for higher education and community colleges predated the current recession and slow growth era. If we look at the period from 2000 to 2010, we find that state and local appropriations for all of higher education increased or stayed about even, in current dollar terms, even though it took funding from the American Recovery and Reinvestment Act (ARRA) of 2009 to keep total support from falling (SHEEO, 2010). In 2010 total support fell by just over $1 \%$ even with ARRA funding. Thus, legislators in most states could rightfully claim that they rarely cut funding for public higher education. However, when we adjust for inflation and enrollments (FTEs) we get a different story.

In the years 2000-10 we encounter the usual roller coaster ride documented in the prior 30year period. With public higher education enrollments rising steadily, state and local appropriations for all of higher education (per FTE adjusted for inflation) rose in 2000-01 but fell in 2002, 2003, and 2004; while rising again in 2005, 2006, 2007 and 2008. However, in 2008 public funding was still $\$ 710$ short of the 2000 level $(\$ 8,035$ vs $\$ 7,325)$. After falling by $5.1 \%$ in 2009 and again by $7.2 \%$ in 2010 , it was more than $\$ 1500$ below the 2000 level $(\$ 6,454$ vs $\$ 8,035$ ) (all figures are per FTE and in 2010 dollars, SHEEO, 2010, Figure 3, p.20). However, as 
mentioned above, the SHEEO data does not separate community college appropriations from other sectors of public higher education. Fortunately the Delta/IPEDS data does.

Community college revenues- When we shift our focus to Delta/IPEDS Project data we find community college revenue data that exhibits the same cyclical pattern that we have documented for all of higher education. The most recent figures show that state and local appropriations for community colleges, per FTE and adjusted for inflation, fell from 1999 to 2000, rose in 2001, but fell in 2002, 2003 and 2004; while rising in 2005, 2006, 2007 and 2008 before falling significantly in 2009. The ups and downs occur in the same years that we described in the paragraph above for all of higher education. However, state and local appropriations were not cut as much for community colleges as they were for other sectors of public higher education. By 2008, state and local appropriations, per FTE and adjusted for inflation, for public research universities were $\$ 750$ below the level of $1999(\$ 10,370$ vs $\$ 9,620)$, and for public master's level colleges they were $\$ 405$ below the 1999 level (\$7411 vs $\$$ 7006). Comparing the figures for community colleges, we find that the 2008 level was $\$ 141$ higher than it was in 1999 ( $\$ 7132$ vs $\$ 6991$ ). It took the recession of 2008-09 to drop the community college appropriations below their 1999 level (Desrochers, et al, 2011).

Selected revenue figures for the community college for the years 1999-2009 are shown in Table 1. As we have described state and local appropriations per FTE, adjusted for inflation, were higher in 2008 than they were in 1999 but the increase was not enough to keep this source of funding from falling as a percentage the community colleges' operating revenue from $57.1 \%$ in 1999 to $52.9 \%$ in 2008 and finally to $51.1 \%$ in 2009 . In response, the share contributed 
by tuition and fees increased from $18.9 \%$ in 1999 to $24.0 \%$ in 2009 . This increased cost sharing is a worldwide phenomenon that has been well documented by Johnstone and Marcucci (2010). My expectation is that this cost shifting will continue in the U.S. and the rest of the world well into the future. As Jones and Wellman (2010) have warned "the prospects of higher education's being elevated to a higher national priority.....are slim to none"(p.10).

Table 1 here

However, even though state and local appropriations are declining as a share of community college revenues, they still provide a much greater proportion of those budgets than they do for either public master's level or public research colleges (51.1\% vs $35.5 \%$ and $25.1 \%$ respectively in 2009). Because community colleges have less access to other sources of revenue, such as research grants and endowment income, than many four-year colleges, their total operating revenue increased by only $6.4 \%$ vs $10.4 \%$ for public master's level colleges and 11.7\% for public research institutions from 1999 to 2009.

\section{Community college expenditures/costs}

Table 2 provides a quick look at the expenditure side of the budget from a national perspective. It shows the expenditures or costs per FTE adjusted for inflation for the most recent years we have data, 1999-2009. Aside from the standard IPEDS expenditure categories divided into instructional, student support, etc., I have listed the expenditures that come closest to representing the cost of educating each student-education and related expenses (E\&R) per FTE adjusted for inflation. This measure includes spending on instruction, student services, and the administrative share and maintenance costs associated with instruction. Since colleges are 
producers of many services, this E\&R expenditure is often used by researchers as "a proxy for the full cost of [educating students]" (see Desrochers, et al, 2010, p.18). The Appendix contains the definition of each of these expenditure categories.

Table 2 here

Looking at Table 2, we can see that community college costs per student have decreased over the past ten years for all categories except research, student services and operations and maintenance. Total E\&R expenditures was almost exactly the same in 2009 as it was in 1999, rising by only $0.4 \%$ over this entire ten year period (also see Table 3 ). When looking at the shares that make up the education and related category, the shares going to direct instruction, which is almost exclusively faculty salaries and fringes, has fallen the most, while the share devoted to academic and administrative support has increased the most. Within the latter support category, expenditures on academic support, such as libraries, have fallen; but those devoted to institutional support, such as executive management, have risen.

Another clue as to the relative cost of operation and instructional and administrative expenditures may be gleaned from the price indices attached to them. The higher education price index (HEPI) measures the prices/costs of the inputs that go into producing educational outputs. Comparing the overall cost of operation, the HEPI for 2002-2010 shows that the community colleges are less expensive to operate than other public colleges (HEPI, 2010,Table C). When looking at the indices for both faculty and administrative salaries, the index for the former stood at 280.6 while that of the latter was $337.6(1983=100)$. This means that administrative salaries have risen faster than faculty salaries (HEPI, 2010, Table B). However, 
the most recent study of staffing costs by SHEEO (Zaback, 2011) shows that executive/administrative and management staff per 100 student FTE's at community colleges was reduced by more than faculty per student 100 FTE's from 2001 to 2009 (22 percent vs 6 percent). Thus, it appears that the proportional shift to expenditures on administration may be explained by rising salaries rather than increased personnel.

Comparative public sector costs--It is worth noting that when looking at national data, all of the cost increases for the community colleges that we have been talking about are very small or negative both in percentage and in real dollar terms. As Table 2 shows, the direct costs of instruction, adjusted for inflation, actually fell by $2.7 \%$ from 1999 to 2009 and E\&R increased by only $0.4 \%$. That is below, or in line with, the general increase in the cost of living as measured by the consumer price index $(\mathrm{CPI})$. The $E \& R$ increase over this same ten year period for public master's level colleges and public research colleges is roughly ten times that of the community colleges at $9.4 \%$ and $10.9 \%$ respectively. This is well above the CPI.

The relative thriftiness of the community college is also apparent when we expand the E\&R category of spending to education and general (E\&G) and the total operating expenditures. Table 2 shows that from 1999 to 2009 the E\&G expenditures for community colleges declined by $3.7 \%$. The comparable figures for public master's level and for public research colleges were increases of $2.5 \%$ and $9.1 \%$ respectively. The total operating expenditures show the same pattern with a zero percent change at the community college but an increase of $5.5 \%$ and $13 \%$ respectively in the other two sectors of public higher education. Certainly for the community 
colleges, this hardly represents costs that are "out of control" as some critics of higher education would have us believe.

Table 3 breaks out the share of public colleges' revenue coming from state and local appropriations compared with the published price of tuition and fees for each sector. It shows that, along with public research and master's level colleges, state and local support per FTE, after adjusting for inflation, was lower in 2009 than it was in 1999. For the community colleges it was actually higher by 2008 but the cuts in 2009 put it below the 1999 level. This allowed community colleges to keep tuition and fees down, increasing by just $\$ 587$ over the entire ten year period.

It appears that state and local governments have been more generous to community colleges than to their four-year public counterparts over the past ten years and that the colleges have in turn been more cost conscious. However, our national data masks what is happening in individual states. In the battles over the 2011-12 state budget appropriations, for instance, some states like New York and Pennsylvania cut other sectors of public higher education more than their community colleges but other states, such as Arizona, did the reverse (Moltz, 2011b).

Table 3 here

\section{Additional Comments on output, productivity, costs and prices}

Output. Like any other producer of goods or services, colleges receive revenues in return for the output they produce. Productivity affects the cost and price of that output. However, measuring the output (or outcomes) of education is a tricky matter. Colleges might want to 
emphasize that learning is their major output, but no standard measure of learning that can be easily explained to the public has been found. If more learning leads to better jobs and incomes or increased satisfaction, or lower social costs, then colleges could show that public support represents an investment with measurable payoffs. Some of this of course can be demonstrated; in particular, the link between higher education and improved labor market outcomes is well understood and is, in large part, responsible for the rising demand for higher education. It should be noted that this has not reduced the cost of that output or the public's demand to provide the same results or better at a lower cost.

Beyond the ill-defined learning outcomes, the most commonly accepted measure of output is the number of degrees being produced. So degree production has increasingly become a measure of productivity. On this score the community college does not come out very well because graduation rates are low and therefore the cost per degree is high. Wellman, Desrochers and Lenihan (2009) have studied this issue extensively using the Delta Project/IPEDS dataset. They have shown that "public community colleges produce significantly fewer degrees per 100 students enrolled than other sectors"(p.31). However, if the definition of completion is broadened to include certificates and diplomas, the completion rates are about the same as public four-year colleges (Wellman, 2008).

In response to their low graduation rate, community colleges will rightfully argue that graduation is not a good measure of their success. At four-year colleges the vast majority of students enroll with the goal of getting a degree. However, the prime goal of credit seeking students at the community college is often not a degree from that school. Some students are seeking short-term vocational training while others may be attending for a year or less before 
they transfer to a university. Particularly in difficult economic times the community college might have an important role to play as "a safe port in a storm" and that safe port, close to home, may only be temporary and without a degree from that college in mind (Betts \& Mcfarland,1996). Finally, completion rates need to take account of the lower level of academic preparation of the students who enter the community college. After all, students are one of the inputs of the education process. Better quality/more motivated students lead to higher levels of output. Once this is accounted for, it may turn out that the value added by the two-year college is higher than that at the four-year level. This is an area that calls for further research.

In short, the community college is a multi-product firm with different programs and roles. The success or failure of these programs/roles needs to be evaluated in ways that do not always show up in the graduation or completion rate. Nevertheless, as long as it is supplemented with other measures, graduation is a reasonable goal for many students and should be included as one measure of output (student success).

Productivity- Higher education is a very labor intensive industry and colleges have found it very difficult to increase productivity by substituting capital for labor. Instead, in order to economize on this expensive resource, colleges' have taken steps to increase the student-faculty ratio and the percentage of part-time faculty in the classroom. If we examine these two standard measures of productivity, the community college looks like a more efficient organization than public four-year colleges. In 2003-04, for instance, 66.5 percent of the community college faculty were part-timers as opposed to only 29.1 percent for the public four-year colleges (NSOPF, 2004). Likewise, in 2009 student-faculty ratios (on an FTE basis) stood at 22:1 in public two-year colleges vs 15:1 in public four-year colleges. A real difference can also be seen in the 
FTE student to FTE staff (other than faculty) ratio. In community colleges that stood at 10:1 but it was only 5:1 at the public four-year college (Digest, 2010, Table 257). These productivity enhancing measures have certainly helped to control costs but the impact on quality and other measures of student outcomes, such as degree production, is hotly debated.

In fact, some evidence suggests that the increasing use of part-time faculty reduces the graduation rate. Ehrenberg and Zhang (2004) find this to be true at four-year colleges and Jacoby (2006) gets about the same results for community colleges. The impact however is small. Further evidence that the increasing use of part-time faculty has a negative impact on student outcomes at the community college level is provided by Boylan (2010), and Eagan and Jaeger (2009). However, Harris and Goldrick-Rab (2010) argue that even if we increased fulltime faculty at community colleges from the current $33 \%$ to $100 \%$, it would only increase the graduation rate by $10 \%$. They conclude that, compared to other options, eliminating all parttime faculty would be an expensive way to get the graduation rate up for community colleges.

At this point it is fair to say that research on the impact of part-time faculty on student outcomes is indeterminate but it does provide a fertile area for future research. The negative association between the use of part-time faculty and student outcomes, for instance, is challenged by Johnson (2011) who claims that the existing studies have serious methodological flaws.

In an important study of overall degree productivity in the U.S., Bound, Lovenheim and Turner (2010) argue that bachelor's degree completion rates, comparing the high school classes of 1972 and 1992, have declined by 4.6 percentage points (from $50.5 \%$ to $45.9 \%$ ). This decline is attributed to the increasing number of students who first enrolled in community colleges and 
less selective public universities. When this study was first released as a National Bureau of Economic Research Working Paper (2009) it caused quite a stir and a response from Adelman (2009) that if you use transcript data and follow the students out $8 \frac{1}{2}$ years from their high school graduation date, instead of the eight years used in the study, the completion rate is constant.

Starting with similar data, Harris and Goldrick-Rab (2010) adjust degree output figures upward, by taking account of the growth in overall labor costs in the economy. They find that the "decline in bachelor's degree production is [still] nearly 20\%" from 1970 to 2006 (p3.). When looking at their model (including a large number of variables) for community colleges however, they find that degree production per dollar spent remains about the same in that 36 year period. Repeatedly in this study the authors suggest that community colleges may be doing better in achieving their "productivity potential" than other public colleges (Harris \& Goldrick-Rab, 2010, p. 41). This same conclusion can be found in Wellman, Desrochers and Lenihan (2009), who conclude that the "costs per unit of output for public community colleges are quite stable... from 1995 to 2006 [which was the time period they were studying]" (p.31).

Thus, it may be that if we define output in terms of degree/certificate production, community colleges look just as good as other sectors of public higher education. If we come back to measuring costs in the more traditional way, however, we find that increases in efficiency or productivity have not always been great enough to offset the rising costs of inputs. Nevertheless, even in this area, community colleges seem to have done a better job at holding costs down than their four-year public counterparts. That is not to say that actions to improve efficiency have not taken place in all sectors of public higher education. Research universities, 
for instance, have placed lower-cost graduate students and adjunct faculty in large introductory courses aimed at lower-division undergraduates and shifted the excess revenue generated to support the teaching of upper-division undergraduates and/or to even more expensive graduate students. For them, the first two years of undergraduate education have become relative cash cows. As we have stated above, community colleges have kept costs down by substituting adjunct faculty for higher-cost full-timers. All colleges have run fuller classes, cut a greater number of low enrollment sections and offered fewer electives in order to increase faculty student ratios (Moltz, 2011a). In all of this, the quality of the final product, student learning, is assumed, but not known, to remain constant.

Costs-- When looking at college costs, we find that most of the research has been done on fouryear colleges and universities. This research suggests that the underlying costs per student have been rising due to factors such as the "rising cost of technology, student services, and institutional financial aid." Additional factors pushing costs up include, "the unrelenting competition to be the best in every dimension of an institution's activities, and, at research universities, the increased instructional costs of scientific research" (Ehrenberg \& Rizzo, 2004, p.1). How can we relate these underlying cost factors to community college budgets?

The two factors from this list that don't seem relevant to the community college budget are the rising costs of research and the increase in institutional aid. The community college has none of the first and very little of the second so let's drop those factors as cost pushers. Next, the rising cost of student services seems to be important to community college budgets. Table 2 does show that the cost of student services has increased as a share of the budget from 1999 to 2009 (9.9\% to $10.7 \%)$. One could easily argue that it is still too low as the type of student 
entering the community college needs more of these services in order to succeed. Work done by Webber (2011) and Webber and Ehrenberg (2010) suggests that expenditures on student services, especially for those from disadvantaged backgrounds, leads to higher persistence and graduation rates. Since a cut in this sector will likely do harm to college outcome measures, this is likely to continue as a cost pusher.

One factor that is not on the list above is the unrelenting drive for accountability. The increased administrative costs of documenting and reporting student progress and fiscal responsibility to the many stakeholders that oversee public higher education is a factor that will continue to push costs up.

What about the relenting cost of being the best? For many four-year colleges this translates into competition for the best faculty, improved student facilities and more selective admission policies. Most of these would not relate well to the community college. But a corollary of this "be the best" factor does. Community colleges push for greater access for underserved students and for greater service to the local communities that they serve. In addition, they still have an inferiority complex with regard to their place within higher education and in many localities seek the recognition and prestige of their four-year counterparts. This often translates into an attitude that they can be all things to all people and that few tasks are outside their reach. If colleges see an educational void in their communities, they look for ways to fill it. This mission creep might also be a factor in rising four-year college budget costs and it seems to relate well to the community college. 
Finally, the rising cost of technology would seem to impact community college budgets in a similar way that it does for four-year college budgets. In traditional manufacturing industries improvements in technology have lowered costs. But in higher education the addition of more technology into the classroom, for instance, has probably raised costs, although it may have also improved quality (see Archibald \& Feldman, 2011, pp. 67-69 for a discussion of this issue). Colleges have certainly used technology to reduce some costs such as putting the college catalog online and automating payrolls and financial records but these savings are less important than anything that would significantly impact instruction. As we look out into the future many hope that technology, in the form of online instruction, will lower instructional costs. Ehrenberg (2011) highlights the potential for using technology to "help improve learning outcomes and .... reduce the costs of instruction" (p.115). Citing the programs of the National Center for Academic Transformation and the Open Learning Initiative at Carnegie Mellon University, he argues that the coming revolution in technology will change the traditional college structure and its professoriate in fundamental ways (Ehrenberg, 2011, pp. 116-118). Whether technology in this disruptive form will be adopted by community colleges is an open question but the results to date have not been encouraging (Mitchell, 2010).

In its current form online courses at the community college create a higher cost for the college, but not necessarily for the student, than face-to-face instruction and result in lower course completion rates (69\% vs 75\%; Instructional Technology Council, 2011). An extensive analysis of fully online courses covering the entire state of Washington by Xu and Jaggars, (2011) shows "lower success rates on a variety of outcomes, even after controlling for a rich array of student characteristics" (pp. 19-20). In a review of the research on this topic, Jaggars 
(2011) outlines the recommendations that might improve the completion rates in these courses but admits that they "will require a substantial investment of new resources in online learning"(Jaggars, 2011, p.3). Fully online degree programs might be able to be delivered at a lower cost but they will need to break loose from the traditional classroom/seat time/credit model in a way that would bring disruptive innovation to current college organizational structures (Christensen, et al, 2011; Ehrenberg, 2011). The business model needed to bring about such innovation will always confront quality issues.

In addition, one of the most pressing quality problems has not yielded to the influence of technology. That is the teaching of remedial students. Efforts to date in this area have largely been a failure and success in improving its quality will likely come with a higher cost per student (Bailey, Jeong, \& Cho, 2010).

Within the near future and the current institutional structures, therefore, modern technology would seem to be a factor that will push costs up rather than pull them down. Since the students that colleges produce are one of the inputs that businesses buy, there is a constant demand for knowledge of the latest technology and that is expensive. On another front no college wants to be seen as being behind the technological curve, and students certainly expect wireless campuses and the array of computer and online services that they have become used to. After all, not keeping up with students' technological expectations would have a negative impact on enrollments.

Net Prices- The College Board tracks the net price of colleges in its annual publication-- Trends in College Pricing. It shows that the average published tuition at four-year public colleges rose 
by 24 percent from $2005-06$ to $2010-11$ and by 11 percent over the same period at public twoyear colleges. After considering grant aid and federal tax benefits, however, the net price, adjusted for inflation, for each type of public college, declined over this same five-year period. In fact, for the lowest income students attending a community college, the latest College Board figures show that their net price was negative for 2010-11 (Baum \& Ma, 2010, p.4). A similar result for two-year colleges was found by Scafini and Schwartz (2003) for the years 1989-90 to 1993-94. This fall in the net price underscores Archibald and Feldman's (2011) conclusion that "public two-year institutions have become more affordable"(p.195) for all segments of the income distribution.

While it is certainly true that in some states need-based grant have not kept up with the rise in tuition this is not true for Pell grants in recent years. They have "increased by about 150 percent since $2005-06$, from $\$ 14.4$ billion then to an estimated $\$ 34.4$ billion in 2010-11" (Lederman, 2011, p.1). This has greatly reduced the cost of going to college for low income students. Of the community college students on Pell grants in 2009-10, 70.8 percent of them had an expected family contribution of zero (Baime \& Mullin, 2011). However, at the time of this writing Pell grants are under attack in the debate over the federal budget deficit and it is unlikely that such large increases, if any, can be expected in the near future. As Baum has noted "no matter what kind of Congress we get, the idea that Pell grants will keep growing at this rate is unlikely" (Jaschik, 2010, p.1).

In addition, one difficulty with net price data cited above is that much of the aid is left on the table by students. This is due, in large part, to the lack of information about its availability and 
the lack of assistance in applying for aid (ACSFA, 2005). Working with the federal financial aid dataset, Kantrowitz (2009) estimated that, at the community college, only 58 percent of Pelleligible students filled out the FAFSA form (compared to $99.5 \%$ of the Pell-eligible students at for-profit, two-year colleges). If students made enrollment decisions based on the net tuition (what they actually pay) rather than the published price, financial barriers would not be as high and more would attend and persist. Colleges need to continue their effort to simplify the financial aid process and to make the information on the net price of attending more accessible. College investments in this area would likely be offset by added revenue. 4

\section{Summary of arguments so far}

1. During the last 40 years enrollments in community colleges have continued to increase, especially during periods of unemployment. State and local appropriations per FTE, adjusted for inflation, however, have declined during periods of unemployment when colleges need it the most.

2. During the past 40 years the public funding for higher education has declined in relative terms, as state and local governments reallocate funds to higher priority programs. This has shifted a greater share of the burden of paying for college, including the community college, from the taxpayers to students/parents. This increased cost sharing is an international phenomenon and is expected to continue well into the future.

3. Compared with other sectors of public higher education, community colleges still get a greater share of their funding from state and local governments, but it varies greatly by state. 
4. The current recession has reduced higher education budgets. Colleges are now dealing with increased enrollments, higher costs, and reduced revenue. National figures indicate that community colleges have not suffered as much as other sectors of public higher education.

5. Increased financial aid has kept up with tuition increases for the lowest income students attending the community college but many students do not apply for this aid and future increases in aid are problematic.

6. Evidence suggests that community colleges have made a good effort in holding down costs and prices through such measures as increasing the faculty student ratio and substituting part-time for full-time faculty. The impact of these productivity enhancing measures on quality is indeterminate.

7. Irrespective of declining state and local support, current trends suggest that the factors pushing college costs up are likely to be stronger than the efforts to improve productivity and control costs. The need for increased revenue, accountability and quality issues will persist.

\section{Policy Issues: Strategies for the new fiscal reality}

Looking at both the revenue and the expenditure sides of the budget from a national perspective, I have argued that community colleges have faired better in the current budget environment than public four-year colleges. State and local appropriations have been cut less and campus efficiencies have kept costs down. One is tempted to recommend that community 
colleges hunker down and wait for an increase in state and local appropriations to relieve their budget stresses. History suggests that this would be a mistake. It would be wiser to anticipate a continuation of the secular decline in public sources of revenue and to prepare for increasing cost pressure from both enrollment increases and a rising cost structure.

Based on the trends described in this study and my own past research, I therefore offer some comments on selected issues that will impact community college budgets in the next ten years or so. In this process I will highlight some of the forces that are likely to shape that future and outline some suggestions for dealing with them. My recommendations are not precise prescriptions for legislative action, but rather suggestions for the direction of public and institutional policy that invite further reflection and research. Increased enrollments In most but not all areas of the country, community colleges will see an increased demand in both degree and non-degree programs. The most optimistic projections of the future need for post-secondary education are offered by Carnevale, Smith and Strohl (2010). They feel that the official Bureau of Labor Statistics projections are underestimating the future needs of the economy and that by 2018, 63 percent of job openings will require workers with some postsecondary education ( p.13). Not all economists, however, agree that the economy will need all of these graduates over the next ten years or so, but even if the market is oversupplied, students are likely to continue to enroll if only to have a better chance for employment in the slots that are available. 
This increased demand will come not only from the recent high school graduates and workers who seek retraining but increasingly from students who are diverted from four-year colleges for financial reasons. Research has shown that the extent of this diversion has not been significant to date (Leigh \& Gill, 2003; Melguizo \& Dowd, 2009), but we can expect it to increase as a result of stagnant incomes among the middle and lower middle income families who populate the community college and less selective four-year colleges. In fact, a recent report indicates that the impact of the current recession on this resorting of college freshman is already underway (Dadashova, et. al, 2011). From a national perspective, this is not necessarily a desirable trend, as students are forced to make choices that may affect their motivation to finish college. Researchers need to continue to follow this process and make sure that the diversion to the community college does not subject these students to an educational penalty (see Long, \& Kurlaender, 2009).

While it may not always be less expensive for the state to educate students for the first two years of a bachelor's degree at the community college it will almost always be less expensive for the student (Romano \& Djajalaksana, 2011). The increased tuition that is inevitable at the two-year level will not be enough to deter most students from attending their local community college because tuition is only a part of the cost of going to college. The lower costs of living at home will more than compensate for the increase in tuition. Moreover, in tight labor markets students will be more reluctant to leave jobs at home for different areas where they are less familiar with the labor market. Thus, a greater percentage of the students who enroll in the community college will be able to afford a higher tuition than is currently being charged in most states. 
Increased need for revenue

Tuition--Rising enrollments will mean a greater need for revenue even if the unit costs per student do not increase. These funds will not come, or will come unevenly, from state and local governments. There is plenty of money out there to pay for college costs but most of it is in private hands. The only way community colleges are going to get their share of it is to raise tuition. In turn, the only way to maintain their historic mission of increased access for underserved populations is to provide more funds for financial aid for those who might be deterred by the rising tuition. College administrators should adopt a strategy to pressure the political system at all levels to increase money for financial aid rather than always pressuring them to direct more funds to support the operating budget as a means of keeping tuition low.

Realizing that calls for increased financial aid may go unheeded, or at best be cyclical, colleges should use funds from the operating budget to provide targeted aid to needy students. These funds will come from tuition increases in excess of the amount needed to cover losses in public funding. Charge those who can afford it and keep some of it to support scholarships or tuition discounts as many four-year colleges now do. The fact that tuition and fees account for less than $25 \%$ of community college revenues nationally means that many states have a ways to go before they reach the more reasonable share of 40-50 percent.

The trick will be to provide institutional aid to students without reducing other types of aid they are eligible for such as Pell grants. Enrollment managers will have the task of distributing aid to those lower income students on the margin who just miss qualifying for other forms of grants, or for helping students substitute institutional aid for loans. 
This does not mean that states will not have an important role to play in financing the community colleges. They will, but the declining priority that has been given to higher education, at least since the 1970's, will likely continue and community colleges should accept the high tuition/high aid strategy to fill that gap. In order for this strategy to work, however, many states will need to give their community colleges more budget flexibility. States like New York have already done this but others like California have not. This means that colleges must have greater flexibility to set their tuition and fees and must be allowed to keep their tuition revenue as well as to carry over operating funds from one year to the next in a fund balance.

High tuition and access--The argument that a low tuition strategy is necessary in order to provide access has lost considerable ground in light of the fiscal problems of the states and their shifting priorities. The equity arguments in favor of such a policy, even for the community college, were always suspect since a low tuition policy which covers all students, subsidies those who can afford to pay at the expense of those who do not attend college at all (Romano, $2003,2005 a, 2005 b)$. The problem is not high tuition but low aid, based on need, in many states.

It is worth noting that low tuition can also be a barrier to access. In a study done in 2003, Romano argued that in the face of declining state support and rising demand, a low tuition state, such as CA, was forced to cut more class sections than did a high tuition state such as NY. This was not only because NY had more tuition revenue but also because it had more budget flexibility than did CA. With a higher tuition and the ability to keep its tuition revenue, NY was able to hire adjunct faculty and even rent physical capacity, and was able to deal with the influx of new students even while state revenues were declining (Romano, 2003). 
With the decline in state revenues in CA in 2010-11, the community college system estimated that 350,000 students would be denied access to college because insufficient funds were available to offer the increased class sections that were needed (Helliker, 2011). Even for the students who were enrolled, a study by the Pearson Foundation found that "nearly a third of community college students were unable to enroll in one or more classes... because they were full" and nearly 30 percent of the students who placed into remedial courses were unable to enroll in such courses due to a shortage of space (Moltz, 2011a, p.1). As long-time students of this process Jones and Wellman (2010) have argued that "reductions in access have fallen most heavily on the community colleges... and low-income and first-generation students. Those students denied access in tough economic times don't simply postpone college entrance; most forego it" (p.8). This suggests that the increased student demand that we have been projecting may not show up as additional college enrollments unless capacity and finance problems in states such as California can be corrected.

Research indicates that a low tuition policy, combined with a colleges' lack of control over their tuition revenue, creates a significant access problem. The inability of community colleges to expand helps explain the rapid rise in enrollments in for-profit colleges by these same students. At the community college level, tuition needs to be high enough to cover the variable costs of instruction. Ideally this would be combined with a high aid policy but equally important, colleges must be allowed to keep their tuition revenue. Allowing tuition revenues to finance other state priorities creates inefficiencies at the campus level and reduces student access. 
Increased reliance on tuition revenues will have its down side. Instead of swings in state and local appropriations colleges will now be more vulnerable to swings in tuition revenues based on FTEs. But revenues will rise as unemployment and enrollments rise, giving colleges the ability to expand their offerings at the time they need it the most. The increased reliance on tuition will also increase the competition for students among institutions, including the forprofits and with online degree and non-degree operations. Advertising, better nonacademic environments and other enticements undertaken by the community colleges will likely increase the cost of education. In addition, the suggestion below, that tuition differentials for different programs be charged, has the potential of alienating students and creating a political backlash that will impose restrictions on the colleges budget flexibility. College managers and researchers will need to keep an eye on this to make sure that it does not deter from the educational mission of the colleges and their ability to generate revenue.

Differential tuition-Many degree programs at the community college are expensive, particularly in the health sciences and technical areas. Romano, Losinger and Millard (2011) have shown that some two-year degrees are more expensive than some four-year degrees. The expensive programs are often in areas where the job prospects for graduates are the best. These students are now being subsidized by the students in less expensive transfer programs and should pay a greater share of their costs of education. In order to do this, colleges need to be aware of the costs of their different programs and the market value of their degrees, so that decisions are evidence based. Romano, Losinger and Millard (2011) and Johnson (2009) have provided some guidance on how these degree costs might be calculated. 3 
Students at the community college are highly mobile between programs, and thus it will be difficult both practically and politically to charge differential tuition rates at the time students enter a program. It would be easier to asses a fee at the course level. This is already being done to some extent by charging lab fees for certain courses. What I am proposing here is a much larger fee (perhaps $\$ 50$ per credit hour in the example below), which makes the student costs of that course closer to the full direct instructional cost of the course. For instance, Romano, Losinger and Millard (2011) have shown that the average cost of each credit hour taught by the dental hygiene (DH) faculty at an upstate community college in the State University of New York is more than five times (\$454 in 2008-09) the cost of each required credit hour of English (\$87 in 2008-09). All indirect and capital costs were excluded. That means that students who take the dental hygiene courses would pay the higher fee for the 48 credits of DH courses in their program, making that degree more expensive. Lower income students will have no trouble including these higher costs in their financial aid packages.

Student loans- It is well known that community college students are more risk averse than fouryear college students. This may be due to cultural differences, among Hispanics for instance, or from a lack of knowledge about the availability of these loans. In any case, more loans will be needed to cover the rise in tuition and fees and the slower income growth that will likely be faced by the lowest income students and their parents. To meet this need, colleges should engage in a long-run political strategy which would shift the emphasis from loans based on the students'/parents' current income to one based on the students future income stream. Federal loans, in particular, would be more progressive and less onerous if they were income contingent. We do some of this in the U.S. but other countries, such as Australia and New 
Zealand, have had much more success with them. We should learn from the experience of other countries and level the playing field with a change in the structure of our student loans (see Johnstone \& Marcucci, 2010 for a full discussion of this issue).

Mission creep

Community college administrators will need some attitude adjustment in a future that is filled with revenue shortfalls. Long being seen as being all things to all people, they need to be more focused on the core missions of the college and to direct resources to fund those missions so that the quality of outcomes can be improved. In this process, colleges will need to be more concerned about the value of what they produce relative to what it costs. Such a cost/benefit mentality will often result in a narrowing of that mission but concerns over the quality of what is done should get added attention.

With tight budgets expected over the next ten years, colleges should not take on roles which spread resources too thin. The recent introduction of the bachelor's degree is a possible case in point. It is more expensive to educate upper-division students, especially in the technical areas, than those at the lower division, and this task will likely drive up unit costs and come at the expense of one of the traditional core missions. Tasks outside the core should only be undertaken if they generate excess revenue which can support the core. Outside observers of the community college have warned about this mission creep for some time (see Breneman \& Nelson, 1981; Osterman, 2010) but it needs to be taken more seriously by insiders. This discussion will likely lead to a new consideration of the meaning of open access. 


\section{Notes}

1. Grapevine data also show the statistical power of the state of California. From FY07 to FY08, for instance, state tax appropriations to community colleges, in current dollars, rose by $6.8 \%$ which was lower than the national average of $7.5 \%$ going to all of higher education. However, the national average for community colleges rose to $7.9 \%$ when California was taken out of the analysis (Palmer, 2008, p.5). California impacts national data so strongly because it enrolls about $25 \%$ of all the community college students and accounts for a similar proportion of state appropriations and because its numbers are often an outlier. The strength of the California pull on national data is also illustrated by the figures on average tuition published by the College Board. The national average for tuition and fees for full-time, in-state students for the 2010-11 academic year, for instance, was $\$ 2,713$, but when California is left out it rises to $\$ 3,076$ (Baum and Ma, 2010, p.10). Researchers are cautioned to check the influence of California before making policy statements that apply to the country as a whole.

2. The accuracy of data on community college expenditures and revenues may decline over time as more colleges take on the role of providing bachelor's degrees. If we think of community colleges as producers of associate's degrees, then the cost of these degrees gets inflated by the inclusion of expenditures on the production of the more expensive upper-division courses. Existing datasets on expenditures do not separate the costs of upper and lower-division undergraduates at the community colleges. 
3. Knowledge of program costs will give colleges the tools they need to argue for increased funding for expensive career programs as well as, or in place of, increases in student fees to support these programs.

4. Preliminary results from a study using H\&R Block software to help low-income families complete the FSFSA form, shows that it dramatically increases enrollment (Bettinger, Long, Oreopoulos \& Sanbonmatsu, 2009).

\section{Acknowledgments}

The author wishes to thanks Donna Desrochers and Jane Wellman for providing a prepublication copy of their Delta Project data for this study. Thanks also to Ronald Ehrenberg (Cornell University), Barbara Viniar (Chesapeake College) and Donald Dellow (University of South Florida) for their comments on a draft of this paper.

\section{References}

Adelman, C. (2009). Comments on Bound, et al. study posted on December 8, 2009 in Inside Higher Education. Retrieved from:

http://www.insidehighereducation.com/news/2009/12/08/attainment.

Advisory Committee on Student Financial Assistance (ACSFA, 2005). The Student Aid Gauntlet: Making Access to College Simple and Certain. Final Report of the special study of simplification of need analysis and application for Title IV aid. Retrieved from: http://www.ed.gov/about/bdscomm/list/acsfa/edlite-gauntlet.html

Archibald, R.B. \& Feldman, D.H. (2008). Explaining increases in higher education costs. Journal of Higher Education, 79 (3), 268-295.

Archibald, R.B. \& Feldman, D.H. (2011). Why does college cost so much? New York: Oxford University Press. 
Bailey, T., Jeong, D.W. \& Cho, S-W (2010). Referral, enrollment and completion in developmental education sequences in community colleges. Economics of Education Review, 29(2), 255-270.

Baime, D.S. \& Mullin, C.M. (2011). Promoting educational opportunity: The Pell grant program at community colleges (Policy Brief 2011-03PLB). Washington DC: American Association of Community Colleges.

Baum, S.,\& Ma, J. (2010). Trends in college pricing. Washington DC: The College Board. College Board, Trends in College Pricing 2010.

Baumol, W. J., \& Bowen, W. G. (1966). Performing arts: The economic dilemma. New York, NY: Twentieth Century Fund.

Baumol, W.J. (1967). Macroeconomics of unbalanced growth: The anatomy of urban crisis. The American Economic Review, 57, 415-426.

Baumol, W.J. \& Blackman, S.A.(1995).How to think about rising college costs. Planning for higher education, 23, 1-7.

Bettinger, E.P., Long, B.T., Oreopoulos, P. and Sanbonmatsu, L. (2009). The Role of Simplification and Information in College Decisions: Results from the H\&R Block FAFSA Experiment. Unpublished paper, Retrieved from: http://gseacademic.harvard.edu/ Iongbr/Bettinger_Long_Oreopoulos_Sanbonmatsu__FAFSA_experiment_9-09.pdf

Betts, J.R. \& McFarland, L.L.(1996). Safe port in a storm: The impact of labor market conditions on community college enrollments. The Journal of Human Resources, 30 (4), 741-765.

Bound, J., Lovenheim, M., \& Turner, S. (2009) Why Have College Completion Rates Declined? An Analysis of Changing Student Preparation and Collegiate Resources. Washington, D.C.: National Bureau of Economic Research, Working Paper 15566. Retrieved from: http://www.nber.org/papers/w15566

Bound, J., Lovenheim, M., \& Turner, S. (2010) Why have college completion rates declined? An analysis of changing student preparation and collegiate resources. American Economic Journal: Applied Economics, 2, 129-157.

Bowen, H. R. (1980). The costs of higher education: How much do colleges and universities spend per student and how much should they spend? San Francisco, CA: Jossey-Bass. 
Boyd, D.J. (2009). What will happen to state budgets when the money runs out?, Albany, N.Y.: Rockefeller Institute of Government. Retrieved from:

http://www.rockinst.org/pdf/government finance/2009-02-19-What Will Happen to.pdf

Boylan, R.T. (2010). States' responses to fiscal droughts and riches. Working Paper, Rice University, Social Science Research Network. Retrieved from:

http://papers.ssrn.com/sol3/papers.cfm?abstract id=1641360

Breneman, D. W. \& Nelson, S. C. (1981). Financing community colleges: An economic perspective. Washington, D.C.: Brookings Institution.

Breneman, D. (2000). An Essay on College Costs. Retrieved October 11, 2010. from

http://curry.edschool.virginia.edu/admin/deans/Breneman/essay\%20on\%20college\%20costs .pdf.

Carnevale, A.P., Smith, N. \& Strohl, J. (2010). Help wanted: Projections of jobs and education requirements through 2018. Georgetown University Center on Education and the Workforce. Washington, DC: Georgetown University.

Christensen, C.M., Horn, M.B., Soares, L. \& Caldera,L. (2011). Disrupting college.Washington, D.C.: Center for American Progress. Accessed 2/11/2011.

Dadashova, A., Hossler, D., \& Shapiro, D. (2011) National postsecondary enrollment trends: Before, during and after the great recession. Herndon, VA: National student clearinghouse research center. Retrieved from:

http://www.studentclearinghouse.info/signature/1/NSC Signature Report 1.pdf

Delaney, J.A. \& Doyle, W.R. (2011). State spending on higher education: Testing the balance wheel over time. Journal of Education Finance. 36(4), pp. 343-368.

Desrochers, D.M., Lenihan, C.L. \& Wellman, J.V. (2010). Trends in college spending- 1998-2008. Washington, DC: Delta Cost Project. Retrieved from: www.deltacostproject.org

Desrochers, D.M., Lenihan, C.L. \& Wellman, J.V. (2011). Trends in college spending- 1999-2009.

Washington, DC: Delta Cost Project. Retrieved from: www.deltacostproject.org

Eagan Jr., M.K. \& Jaeger, A.J. (2009). Effects of exposure to part-time faculty on community college transfer. Research in Higher Education, 50, pp. 168-188.

Ehrenberg, R.G. \& Zhang, L. (2004). Do tenure and tenure-track faculty matter? NBER Working Paper 10695. Cambridge, MA: National Bureau of Economic Research

Ehrenberg, R.G. \& Rizzo, M.A. (2004). Financial forces and the future of American higher education. Academe, July-August. 
Ehrenberg, R.G. (2011). Rethinking the professoriate. In Wildovaky, B., Kelly, A.P., Carey, K. (eds.). Reinventing Higher Education. Cambridge MA: Harvard Education Press.

Harris,D.H. \& Goldrick-Rab, S. (2010). The (un)productivity of American higher education: From cost disease to cost-effectiveness. LaFollette School of Public Affairs, University of Wisconsin-Madison. Working Paper No. 2010-023.

Helliker, K.(2011). High enrollment strains two-year colleges. The Wall Street Journal. February 9, Accessed 3/17/2011.

HEPI (2010). The Commonfund Institute-2010 HEPI update. Retrieved from: http://www.commonfund.org/CommonfundInstitute/HEPI/HEPI\%20Documents/2010/CF_HEPI _2010.pdf

Instructional Technology Council (2011). 2010 Distance Education Survey Results, Washington, D.C.: Author

Jacoby, D. (2006). Effects of part-time faculty employment on community college graduation rates, The Journal of Higher Education, 77 (6), 1081-1103.

Jaggars, S.S. (2011). Online learning: Does it help low-income and underprepared students? CCRC Brief, Community College Research Center, Columbia University, New York.

Jaschik, S. (2010), Tuition hikes of the downturn. Inside Higher Education, October 28. Retrieved from: http://www.insidehighered.com/news/survey/president2011/tuition

Johnson, I.Y. (2011). Continent instructors and student outcomes: An artifact or a fact? Research in Higher Education. Published online: 20 February.

Johnson, N. (2009). What does a college degree cost? A Delta Project White Paper. Washington, DC: Delta Project on Postsecondary Costs, Productivity, and Accountability. Retrieved from http://www.deltacostproject.org/resources/pdf/johnson3-09_WP.pdf

Johnstone, B.D. \& Marcucci, P.N. (2010). Financing higher education worldwide. Baltimore: Johns Hopkins University Press.

Jones, D. \& Wellman, J. (2010). Breaking Bad Habits: Navigating the Financial Crisis

Change, May-June. Retrieved from: http://www.changemag.org/Archives/Back\%20lssues/MayJune\%202010/breaking-bad-full.html

Kantrowitz,M. (2009). FAFSA completion by level and control of institution. Retrieved from: http://www.finaid.org/educators/20091014fafsacompletion.pdf

Katsinas, S.G. \& Friedel, J.N. (2010). Uncertain recovery: Access and funding issues in public higher education. University of Alabama Education Policy Center. 
Lederman, D.(2011). A plea to cut Pell wisely. Inside Higher Education, April 18, 2011.

Leigh, D.E. \& Gill, A.M. (2003). Do community colleges really divert students from earning bachelor's degrees? Economics of Education Review, 22, 23-30.

Leigh, D. \& Gill, A. (2004). The effects of community colleges on changing students'educational aspirations. Economics of Education Review, 23(1), 95-102.

Long, B. T.\& Kurlaender, M. (2009) Do community colleges provide a viable pathway to a baccalaureate degree? Educational Evaluation and Policy Analysis, 31 (1), 30-53.

Melguizo, T. \& Dowd, A.C. (2009). Baccalaureate success of transfers and rising four-year college juniors. Teachers College Record, 111 (1), 55-89. Retrieved from:

http://cue.usc.edu/tools/Melguizo Dowd Baccalaureate\%20Success\%20of\%20Transfers\%20and\%20Risi ng\%20Four\%20Year\%20College\%20Juniors TCR\%20in\%20press.pdf

Mitchell, R.L.G.(ed) (2010). On line education. New Directions for Community Colleges, No.150, Jossey-Bass.

Moltz, D. (2011a). Left in the hall. Inside Higher Education, February 9. Accessed 2/9/2011.

Moltz, D. (2011b). Triage funding for community colleges. Inside Higher Education, March 31.

Assessed 2/10/2011.

Mullin, C.M. \& Phillippe, K. (2009). AACC Policy Brief 2009-01 PBL. Retrieved from:

http://www.aacc.nche.edu/Publications/Briefs/Pages/rb12172009.aspx

NCES (2008). Community colleges: Special supplement to the condition of education, Washington, DC: National Center for Education Statistics.

NCES (2010). Digest of Education Statistics, 2009. Washington, D.C.

NSOFP (2004). National Study of Postsecondary Faculty. U.S. Department of Education, National Center for Education Statistics. Data Analysis System.

Osterman, P. (2010). Community colleges: Promise, performance and policy. Paper prepared for the American Enterprise Institute conference, Reinventing the American University: The Promise of Innovation in Higher Education, June 3.

Palmer, J.C. (2008). Grapevine, Normal,IL: Illinois State University, Center for the study of education policy. Retrieved from: http://www.grapevine.ilstu.edu/ 
Rizzo, M (2004). A (less than) Zero sum game? State funding for public education: How public higher education institutions have lost. PhD dissertation, Cornell University. Retrieved from: http://www.ilr.cornell.edu/cheri/workingPapers/upload/cheri_wp52.pdf

Rizzo, M. (2006). A Panel Data Analysis of State Preferences for Funding Higher Education: 1977-2001, in American Council of Education, What's Happening to Public Higher Education, (Greenwood Press, 2006).

Roessler, B. C. (2006). A quantitative study of revenues and expenditures at U. S. community colleges, 1980-2001. Unpublished doctoral dissertation, University of North Texas, Denton.

Romano, R.M. (2003). Financing community colleges across the states: An economic perspective. Prepared for a conference on the Complex Community College, Cornell University, Ithaca, N.Y. October, 2003. Retrieved from:

http://www.ilr.cornell.edu/cheri/conferences/upload/2003oct/chericonf2003_08.pdf

Romano, R.M. (2005a). Seeking the Proper Balance Between Tuition, State Support and Local Revenues: An Economic Perspective. In Stephen G. Katsinas and James C. Palmer (eds.), Sustaining Financial Support for Community Colleges, New Directions for Community Colleges, no. 132. Jossey-Bass.

Romano, R.M. (2005b).Privatizing the community college, Community College Journal, pp. 22-26.

Romano, R.M., \& Djajalaksana, Y.M. (2011). Using the community college to control college costs: How much cheaper is it? Community College Journal of Research and Practice.

Forthcoming.

Romano, R.M., Losinger, R. \& Millard, T. (2011). Measuring the cost of a college degree: A case study of a SUNY community college. Community College Review. Forthcoming.

Scafidi, B.P. \& Schwartz, A.E. (2003). What's “up” with the price of two-year colleges? Paper presented at a conference on The complex community college, at Cornell University, October 13-14. Retrieved from: http://www.ilr.cornell.edu/cheri/conferences/complexCommCollege.html

SHEEO (2010). State higher education finance- FY 2010. State higher education executive officers.

Webber, D.A. (2011). Expenditures and postsecondary graduation: An investigation using individual-level data from the state of Ohio. Cornell Higher Education Research Institute, Working Paper \# 140. Retrieved from:

http://www.ilr.cornell.edu/cheri/workingPapers/upload/Ohio_expenditures.pdf 
Webber,D.A. \& Ehrenberg, R.G. (2010). Do expenditures other than instructional expenditures affect graduation and persistence rates in American higher education? Economics of Education Review, 29, pp. 947- 958.

Weisbrod, B.A., Ballou, J.B., \& Asch, E. D. (2008). Mission and Money, New York: Cambridge University Press.

Wellman, J. (2008). Improving legislative oversight of college costs. Powerpoint presentation, NCSL seminar for fiscal analysts, Madison, WI, September 25. Retrieved from:

file:///E:/CCR\%20Finance\%20Article/wellman_wi_2008-09-25.ppt\#394,13,Slide 13

Wellman, J.V., Desrochers, D.M., \& Lenihan, C.M. (2008). The growing imbalance:

Recent trends in U.S. postsecondary education finance. Retrieved from:

http://www.deltacostproject.org/resources/pdf/imbalance20080423.pdf

Xu, D. \& Jaggars, S.S. (2011). Online and hybrid course enrollment and performance in Washington state community and technical colleges. CCRC Working Paper \#31, Community College Research Center, Columbia University, New York. Retrieved from:

http://ccrc.tc.columbia.edu/Publication.asp?UID=872

Zaback, K. (2011). Staffing trends in public colleges and universities: A national analysis 20012009. State Higher Education Executive Officers. Retrieved from:

http://www.sheeo.org/pubs/Fall Staffing-Final05-24-2011.pdf 
Table 1 Average Community College Revenues per FTE and percentage of Total Operating Revenue for Selected Years, 1999-2009 (2009 dollars)

\begin{tabular}{lccccccccc} 
Source & $1999(\%)$ & 2001 & 2005 & 2006 & 2007 & 2008 & 2009 & $(\%)$ \\
\hline Net tuition & & $\$ 2,307(18.9)$ & 2,356 & 2,830 & 2,898 & 2,990 & 3,005 & 3,118 & $(24.0)$ \\
State and local approp. & $\$ 6,991(57.1)$ & 7,058 & 6,195 & 6,615 & 6,900 & 7,132 & 6,645 & $(51.1)$ \\
Public grants \& contracts & $\$ 1,573(12.9)$ & 1,745 & 1,719 & 1,767 & 1,829 & 1,879 & 1,949 & $(15.0)$ \\
Private gifts, grants, income & $\$ 210$ & $(1.7)$ & 218 & 224 & 292 & 372 & 293 & 169 & $(1.3)$ \\
Aux. enterprises \& other & $\$ 1,270(10.4)$ & 1,305 & 1,247 & 1,233 & 1,244 & 1,296 & 1,253 & $(9.6)$ \\
Total Operating Revenue & $\$ 12,233(100)$ & 12,593 & 12,176 & 12,661 & 13,193 & 13,474 & 13,012 & $(100)$
\end{tabular}

Adapted from pre-publication version of Drochers, et al, 2011. Figures for the omitted years can be found at www.deltacostproject.org. The Appendix contains a definition of these revenue categories. 
Table 2 Average Community College Operating Expenditures per FTE, 1999-2009 and selected shares in percentages (2009 dollars)

\begin{tabular}{|c|c|c|c|c|c|c|c|}
\hline IPEDS Category & 1999 (\%) & 2001 & 2005 & 2006 & 2007 & 2008 & $2009(\%)$ \\
\hline Instruction & $\$ 5,242(43.1) \quad 5$ & 5,350 & 4,843 & 4,969 & 5,147 & 5,251 & $5,103(43.6)$ \\
\hline Research & $\$ 54(0.4)$ & 41 & 46 & 63 & 53 & 50 & $64 \quad(0.5)$ \\
\hline Public service & $\$ 402(3.3)$ & 439 & 365 & 370 & 353 & 364 & $351 \quad(3.0)$ \\
\hline Academic support & $\$ 1,027(8.4)$ & 1,075 & 925 & 954 & 981 & 1,013 & $990(8.5)$ \\
\hline Student services & $\$ 1,207(9.9)$ & 1,219 & 1,175 & 1,204 & 1,256 & 1,260 & $1,258(10.7)$ \\
\hline Institutional support & $\$ 1,794(14.7)$ & ) 1,849 & 1,691 & 1,754 & 1,823 & 1,890 & $1,842(15.7)$ \\
\hline Op. and maint. (O\&M) & $\$ 1,095(9.0)$ & 1,158 & 1,110 & 1,195 & 1,232 & 1,243 & $1,224(10.4)$ \\
\hline Net scholarships & $\$ 1,533(12.6)$ & 1,662 & 1,019 & 949 & 923 & 1,008 & 1,163 (9.9) \\
\hline Total Ed. \& General & $\$ 12,163(100) 1$ & 12,606 & 10,939 & 11,221 & 11,552 & 11,837 & $11,713(100)$ \\
\hline
\end{tabular}

$\begin{array}{llllllll}\text { Aux enterprises \& other } \quad \$ 886 & 908 & 1,069 & 1,054 & 1,135 & 1,237 & 1,308\end{array}$

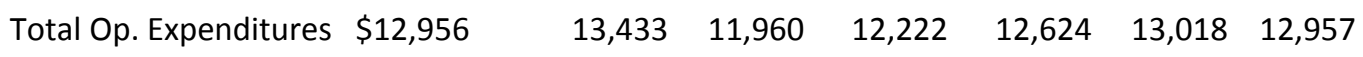

SHARES of Education and Related Spending, 1999,2001, 2005-2009 and selected percentages

Education and related $\quad \$ 10,204 \quad \$ 10,472 \quad \$ 9,595 \quad \$ 9,922 \quad \$ 10,298 \quad \$ 10,496 \quad \$ 10,242$

$\begin{array}{lll}\text { Instruction } & (51.7 \%) & (49.9 \%)\end{array}$

Student services $\quad(11.7 \%) \quad(12.2 \%)$

Acad, admin, + O\&M $\quad(36.6 \%)$

Adapted from Delta Project IPEDS database, 11 year matched set (Desrochers, et al, 2011) .Data may not sum to totals because expenditures were summed at the institution level before calculating aggregate category averages. May not add to $100 \%$ due to rounding. See Appendix for definition of categories and shares. 
Table 3 Tuition and fees (sticker price); State and Local Appropriations vs Education and Related Expenditures by Sector, 1999-2009 (per FTE in 2009 dollars)

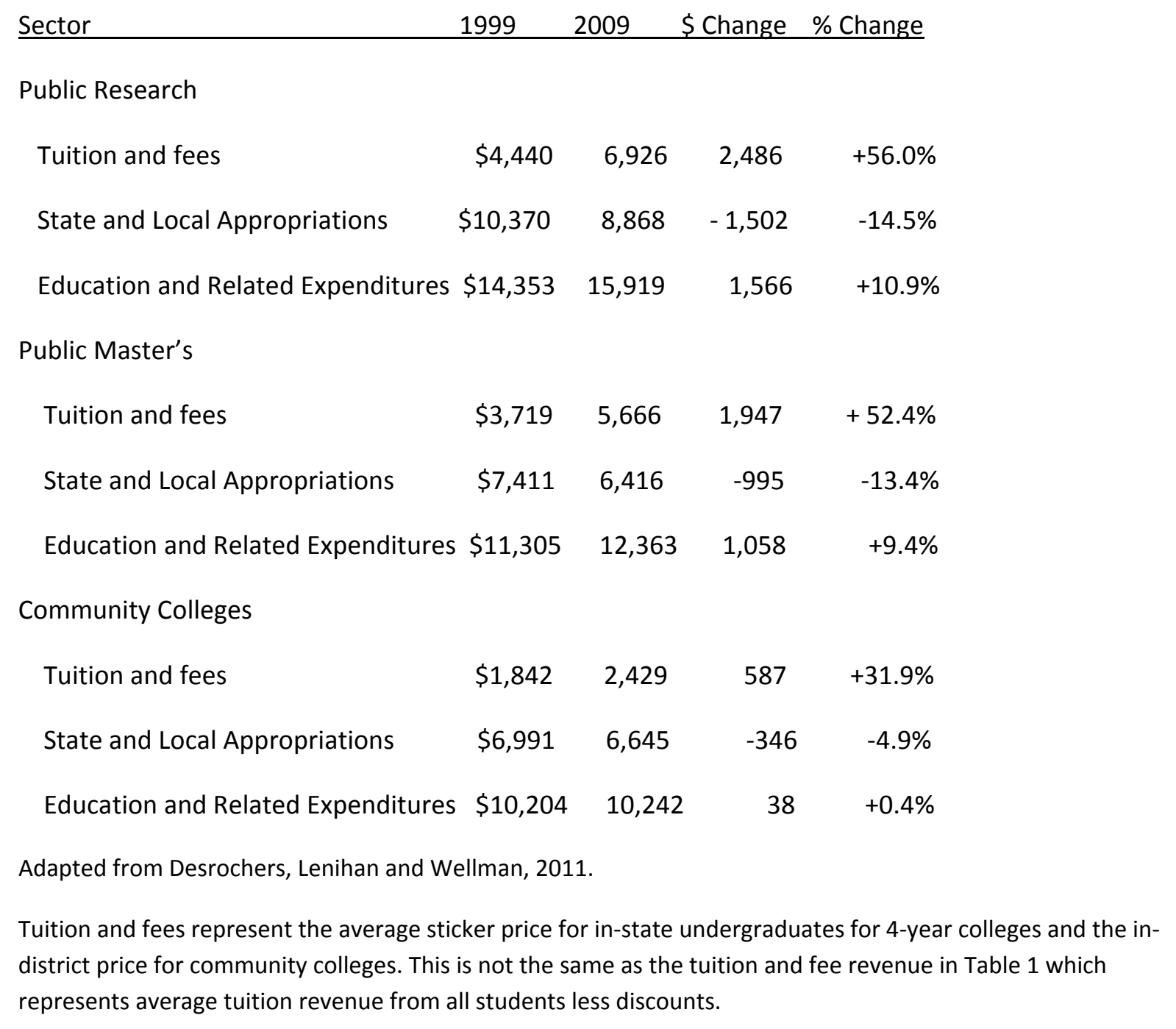

